\title{
IN DEFENSE OF SUPERNATURAL PURPOSE THEORY
}

\section{STEWART GOETZ}

\section{Ursinus College}

I want to thank Thaddeus Metz and the editors of the European Journal for Philosophy of Religion for inviting me to contribute to this discussion of his book Meaning in Life: An Analytic Study. ${ }^{1}$ This is the second time I have had the privilege of interacting with Metz's book. My first opportunity was in my review of it in the June 6, 2014 Notre Dame Philosophical Review. In this essay, I begin with the seemingly irresolvable ultimate conflict that exists on Metz's view between one's own happiness, which (contrary to Metz) I believe is the most basic form of meaning in life, and being moral. This discussion naturally leads to consideration of supernatural purpose theory about life's meaning. I will briefly try to defend a certain form of it. Finally, I close with a few comments about the intuitive plausibility of the hedonistic view of life's meaning that I believe is correct.

I.

According to Metz, 'ultimately happiness and meaningfulness [...] form two of the largest and most fundamental values in human life.' With regard to meaningfulness, he advocates what he calls 'the fundamentality theory', which is a form of objective naturalism in which meaning in life comes from actively orienting one's rational nature, which in the first instance involves cognition and intentional action, but extends to rationally responsive conation (e.g., desire), emotion (feeling joy upon awareness of a loved one's success) and affection (e.g., like a work of art), to the fundamental values of the good, the true, and the beautiful.

${ }^{1}$ Thaddeus Metz, Meaning in Life: and Analytic Study (Oxford: Oxford University Press, 2013).

${ }^{2}$ Metz, Meaning in Life, p. 60. 
Let us consider the good, of which moral action, according to Metz, is a central pillar. ${ }^{3}$ Metz is an objectivist about the moral good: certain actions/behaviours are objectively right and others are objectively wrong, where the moral wrongness of an action provides a categorical reason not to perform that action. For example, 'claiming that it is wrong to torture babies for fun does include an overriding reason not to do something, which reason obtains regardless of one's desires and interests. ${ }^{3}$ Metz believes that objective morality obtains in a naturalist world that has the following three characteristics. First, it is a world in which we experience pleasure and where, as Metz acknowledges, these experiences of pleasure make up our happiness. ${ }^{5}$ Second, it is a world in which our ultimate end is death/annihilation. And, third, it is a world in which behaviours that are morally right at least sometimes do not promote the agent's happiness. Indeed, those behaviours either amount to a restraint on the agent's pursuit and improvement of his or her happiness or actually undermine that happiness by directly or indirectly producing experiences of pain. Given that this is the case and the fact that Metz acknowledges that happiness is one of the 'largest and most fundamental values in human life, an obvious question that arises is why does the reason for performing the morally right behaviour override the reason for performing an action that makes for the agent's greater happiness?

As best as I can tell, Metz never answers this question. Rather, he simply assumes that the morally right action is overall the most reasonable, even at the expense of the agent's own happiness. But why does moral value trump this non-moral value? A response might be that jettisoning morality for the maximization of one's own happiness is immoral. It is. But when one is cognizant that this is the only life one has to live (death is the absolute end of one's existence) and, therefore, the only life in which one will have the opportunity to experience the intrinsic goodness of pleasure/happiness, why not choose one's own happiness over performing the morally right action?' ${ }^{6}$ Metz might respond that

${ }^{3}$ Ibid., pp. 91-3.

${ }^{4}$ Ibid., p. 92.

${ }^{5}$ Ibid., pp. 60, 78 .

${ }^{6}$ In my review of Meaning in Life in the Notre Dame Philosophical Review, I raised a similar issue concerning the likelihood that meaning in life (as Metz understands it) and happiness for oneself, which Metz maintains are distinct fundamental values, might 
orienting one's rational nature toward the moral good is part of a more meaningful life. And one wants a meaningful life because it is a large and fundamental good. But one's happiness is also such a good and it is not obvious that meaningfulness in life is preferable to happiness.

Now, there is a perfectly reasonable understanding of the question 'Is life meaningful?' that means 'Do things ultimately make sense?', where 'Do things ultimately make sense?' means 'Do things ultimately fit together in the right way?' The problem presently under consideration is this: If the immoral course of action will ultimately yield more happiness for an agent than the moral course of action, it seems that things ultimately don't fit together as they should. Commonsensically, for things to fit together in the right way it should be the case that those who pursue the morally right course of action ultimately end up happier than those who choose the immoral route. In other words, it seems eminently reasonable to think that morality and happiness should not pull apart and run on ultimately non-converging rails. They should ultimately come together. Given this is the case, John Cottingham's comments about reasons for action merit quoting:

If our reasons for action flow merely from what is good, then if we are rational and unbiased we may recognize an obvious good in some action that serves the interests of others; but we can also recognize a clear and equally valid good in an alternative action that serves our own personal interests. And it's simply not clear from rational analysis alone why the former (the altruistic reason) should have any overriding force. [...] Merely considered in terms of rational action aimed at the good, there seems no reason to give up one's own good for the sake of others.?

Thus, while it seems to Metz that a moral consideration is always overriding, it is reasonable to think that this appearance presupposes that acting morally ultimately harmonizes with one's long-term happiness. But in a naturalistic world this harmonization is not guaranteed and is all too often absent. Therefore, the overriding nature of a moral consideration is no longer apparent because it is no longer real.

ultimately conflict in an irresolvable way. If such were the case, why think that it would be more reasonable to choose meaning over happiness?

${ }^{7}$ John Cottingham, Philosophy of Religion: Towards a More Humane Approach (Cambridge: Cambridge University Press), p. 82. 
II.

Erik Wielenberg writes that in a godless [naturalistic] universe there is at best a rough correlation between morality and self-interest [...] Without God, there is always the possibility that we will face a deep conflict between what is in our own self-interest and what morality requires of us. That is an important difference between a theistic universe and a godless universe.' With mention of God, we enter the explanatory space that Metz terms 'purpose theory' about the meaning of life. While there are different versions of purpose theory, ${ }^{9}$ one that fits the present context best will include at least the following elements: God (a substantively simple, omnipotent, omniscient, omnibenevolent being) exists and creates a human person for the purpose that he or she experience perfect happiness, where (i) perfect happiness is the unending experience of nothing but pleasure, (ii) experiencing perfect happiness constitutes a meaningful life, and (iii) a necessary condition of experiencing perfect happiness is that one choose in the morally right way (more about this in a moment). Metz says several things that are relevant to this version of purpose theory (from here on, the purpose theory), some that are supportive and some that are sceptical. I begin with the supportive.

Metz points out that some philosophers have maintained that God's creating human persons for a purpose would disrespect them. Here, he discusses Kurt Baier's claim that 'the purpose theorist "sees man as a creature, a divine artefact, something halfway between a robot (manufactured) and an animal (alive), a homunculus, or perhaps a Frankenstein, made in God's laboratory, with a purpose or task assigned him by his Maker"'. ${ }^{10}$ Metz says that 'Baier might therefore suggest this principle to govern the creation of rational beings: it is disrespectful to create a person for any purpose other than to pursue its own purposes.' ${ }^{11}$ Thomas Nagel has expressed Baier's objection by wondering what one would say if one were told that the purpose for which one had been created was to be food for another species. ${ }^{12}$

${ }^{8}$ Erik J. Wielenberg, Robust Ethics: The Metaphysics and Epistemology of Godless Normative Realism (Oxford: Oxford University Press, 2014), p. 59.

${ }^{9}$ Metz, Meaning in Life, p. 82.

${ }^{10}$ Ibid., p. 103. The quote is from Kurt Baier, 'The Meaning of Life', in E. D. Klemke (ed.), The Meaning of Life, 2nd edition (Oxford: Oxford University Press, 2000), p. 120.

${ }^{11}$ Metz, Meaning in Life, p. 103.

12 Thomas Nagel, 'The Absurd', in E. D. Klemke (ed.), The Meaning of Life, 2nd edition (Oxford: Oxford University Press, 2000), p. 180. 
The purpose theorist, as Metz rightly points out, must hold that it can be respectful to create persons for a purpose other than that of adopting their own purposes. ${ }^{13}$ Whether or not it is respectful will depend, at least in part, upon what the purpose is. What if the purpose is that created persons be perfectly happy? It is hard to see how this could be disrespectful because perfect happiness is a great good. Indeed, it is an individual's greatest good. In Metz's own words, 'people who are sane and autonomous would invariably want eternal bliss. ${ }^{14}$ Hence, they could not reasonably consider themselves disrespected upon coming to believe they were created to experience perfect happiness.

Given that any sane person would want perfect happiness, there is an answer to a slightly different objection to the purpose theory that Baier presents. According to Metz's summary of Baier's charge, being created for a purpose would 'treat one's capacity for rational choice as a mere tool to be used for the realization of a purpose that one does not share. It is irrelevant that realizing the purpose would be good for oneself; that would merely add a paternalistic aspect to the degradation. ${ }^{15}$

Once again, Baier's assertion is highly dubious. Given that no one can choose the bad for its own sake and choosing to reject perfect happiness is doing just that, no sane person could choose to reject (not share) the purpose that he or she be perfectly happy. And because being perfectly happy is a human being's greatest good, Baierian allegations that being created for the purpose that one be perfectly happy is coercive or exploitive ${ }^{16}$ are groundless, if not senseless.

While the purpose theory says God creates persons for the purpose that they experience perfect happiness, a version of it also holds that it is possible for persons not to fulfil this purpose. While all persons experience some degree or other of happiness, and thereby confirm Metz's belief that meaning in life is a gradient property; something that comes in degrees, ${ }^{17}$ some might never come to experience perfect happiness. Why? Because these persons might not make the right choice. Consider two alternatives, one which is pursuing happiness in one's own way and the other which is giving up this option. With the first choice, one insists on retaining the final say about how one will pursue one's happiness

\footnotetext{
${ }^{13}$ Metz, Meaning in Life, pp. 103-4.

14 Ibid., p. 127.

${ }^{15}$ Ibid., p. 102.

${ }^{16}$ Ibid., pp. 100-1.

${ }^{17}$ Ibid., p. 22.
} 
and when, where sooner rather than later is the typical preference. With the second choice, one does not retain this final word. In the Christian tradition of which I am a member, one is told to die to self, to lose one's life, or to bury the seed so that it might come to life. Death, loss, and burial are metaphors for the idea that one chooses to renounce any final claim to a right to pursue the happiness for which one is created on one's own terms. Instead, one chooses to trust one's Creator to provide in the end the happiness for which one is created, which makes rational one's sacrifice of happiness in each and every ante-mortem 'now' when such restraint is morally required.

It is now time to turn to some of the sceptical things Metz says about purpose theory. While he recognizes that 'neither compensatory nor retributive justice is completely achieved in this world, which means that for our lives not to be non-sensical, they must extend beyond the death of our bodies, ${ }^{18}$ it is not clear that perfect justice requires an eternal afterlife:

It seems that humans would deserve an eternity in heaven only if they did something infinitely good, or an eternity in hell only if they did something infinitely bad, and we may reasonably doubt that infinite (dis)values are possible in a finite world [...] Furthermore, even if they were possible, it would not follow that eternity is needed to give people what they deserve; for supposing that one could do something infinitely (dis)valuable in a finite amount of time here on earth, it would seem that a response proportionate to this deed would require merely a finite amount of time. If infinitely good or bad deeds were possible in a finite timespan, then so would punishments and rewards matching these deeds. ${ }^{19}$

Here I believe it is helpful to look at the idea of retributive justice differently than Metz does. Instead of thinking of it in terms of doing some deed that is infinitely good or bad, one should think of it in Kantian (and Baierian) terms of respect for one's autonomous choice about retaining or giving up the prerogative to pursue one's happiness on one's own terms. If one never experiences perfect happiness - never has the purpose for which one was created fulfilled, it is because one refuses to give up the prerogative to pursue happiness as one sees fit. C. S. Lewis captured this idea in the following comments:

\footnotetext{
${ }^{18}$ Ibid., p. 125.

19 Ibid.
} 
If the happiness of a creature lies in self-surrender, no one can make that surrender but himself [...] and he may refuse. [...] Supposing he will not be converted, what destiny in the eternal world can you regard as proper for him? [...] I [...] believe that the damned are, in one sense, successful, rebels to the end; that the doors of hell are locked on the inside. [...] They enjoy forever the horrible freedom they have demanded [to pursue happiness on their terms], and are therefore self-enslaved. ${ }^{20}$

Existence in an afterlife in which one experiences the perfect happiness for which one was created commonsensically seems to require the existence of a soul that exists from this life into the next (the soul is the self or 'I' that remains numerically the same throughout this life and into the next), regardless of whether or not it is embodied in the future life. Some comments about the soul will help in addressing a further sceptical point that Metz makes about purpose theory. As traditionally conceived, the soul is a simple entity in the sense that it does not have substantive parts. Though simple in terms of lacking substantive parts, it is complex in terms of having a multiplicity of properties, some of which are the capacities to experience pleasure and pain, the capacity to desire, the capacity to believe, the power to choose, etc. That the soul is both substantively simple yet complex in terms of its properties is compatible with it existing in space and time. Indeed, up until the time of Descartes, Christian philosophers who wrote about the soul (e.g., Augustine, Aquinas) standardly affirmed both the temporality of the soul and its presence in its entirety at every point in space that it occupied (which typically was believed to be the space occupied by its physical body). ${ }^{21}$

These comments about the soul are relevant because Metz is sceptical about the purpose theory in part because he takes God's simplicity to entail that God must be beyond space and time. And because God must be beyond time, it makes no sense to say that He engages in purposeful activity: 'it is difficult to conceive of a purposive agent who [...] is absolutely simple and therefore can neither change nor act in time.22 But given the intelligibility of the idea that the human soul is simple (in the sense that it has no substantive parts) and acts for purposes while in time, it is not incoherent to affirm that God exists in time and acts for

\footnotetext{
${ }^{20}$ C. S. Lewis, The Problem of Pain (New York: Harper San Francisco, 2001), pp. 120, $123,130$.

${ }^{21}$ For much more on this topic, see Stewart Goetz and Charles Taliaferro, A Brief History of the Soul (Oxford: Wiley-Blackwell, 2011).

${ }^{22}$ Metz, Meaning in Life, p. 114.
} 
purposes. It is true that many theists have affirmed the atemporality of God. My point is that even if Metz is correct and it is nonsensical to hold that such a being can act for purposes, it does not follow that the purpose theory is thereby falsified. God could act for purposes in time, just as created simple souls do. And it is worth stressing at this point that God could act for multiple purposes. Metz argues that acting for multiple purposes would be incompatible with God's simplicity. ${ }^{23}$ But if a simple human soul can exist and act for more than one purpose (e.g., I can write this paper both for the purpose of fulfilling a commitment and the purpose of learning more about meaning in life), there is no good reason to think that God could not do the same.

III.

Belief in the soul's existence is very commonsensical in nature, as I have discussed elsewhere. ${ }^{24}$ Most philosophers who reject its existence do not deny this point but instead argue that common sense is mistaken. The idea that pleasure is intrinsically good and that happiness consists of experiences of pleasure is also thoroughly commonsensical in nature. According to Matthew Silverstein, '[h]edonism [about happiness] is an intuitive theory. ${ }^{25}$ But why think that when someone is interested in the meaning of life he or she is interested in happiness? Is this equally commonsensical? It certainly seems so to me, and Metz recognizes that ' $\mathrm{t}$ ] here are some who might have been inclined to think that a meaningful life just is (substantively) a happy one. ${ }^{26}$ Why might someone like me believe that a meaningful life just is a happy one, and a most meaningful life a perfectly happy one?

My explanation begins with what Metz, like so many others, recognizes, which is that questions like 'What is the meaning of life?' and 'What constitutes meaning in life?' are vague and need clarification.

${ }^{23}$ Ibid., p. 113.

${ }^{24}$ See Goetz and Taliaferro, A Brief History of the Soul; and Stewart Goetz, 'Substance Dualism, in Joshua R. Farris and Charles Taliaferro (eds), The Ashgate Research Companion to Theological Anthropology (Burlington, VT: Ashgate, 2015), pp. 125-37; and T. J. Mawson, 'Substance Dualism', in James Garvey (ed.), The Continuum Companion to Philosophy of Mind (London: Continuum, 2011), pp. 73-91.

${ }^{25}$ Matthew Silverstein, 'In Defense of Happiness: A Response to the Experience Machine', Social Theory and Practice, 26 (2000), 290.

${ }^{26}$ Metz, Meaning in Life, p. 74. 
Hence, it is plausible to think that these questions and others like them are really standing in for a multiplicity of questions, among which there is what Metz thinks of as a family resemblance: 'theories of meaning in life are united by virtue of being answers to a variety of related and substantially overlapping questions that cannot be reduced to anything simpler. ${ }^{27}$ As I have argued elsewhere, I think it is eminently plausible to think the family resemblance is exemplified by the following three questions: 'What, if anything, makes life worth living?', 'What is the purpose of life?', and 'Does life ultimately make any sense in terms of things fitting together in an intelligible way?' ${ }^{28}$ In brief, the answer to the first question is experiences of pleasure. The answer to the second is that we might experience nothing but pleasure. And the answer to the third is that those who choose to die to self will ultimately receive nothing but pleasure. ${ }^{29}$

Metz simply stipulates that to enquire into meaningfulness is 'by definition [not] to enquire into happiness' and, thus, 'it is logically contradictory to think that one's pleasure in itself, the mere experience, is meaningful. ${ }^{30}$ I believe there is nothing I can say that would dissuade Metz from this definitional position. To his credit, he acknowledges how often he appeals to intuitions, ${ }^{31}$ and I believe it is likely that our differences about how to interpret questions about the meaning of life ultimately come down to a difference in intuitions. But I also think it is appropriate that I should say something brief both in response to his understanding of meaning in life and on behalf of my own.

A major concern of mine about Metz's fundamentality theory of meaningfulness (FT) is that it is exclusive in terms of its intellectualism and unattainability. Here is Metz's final formulation of the fundamentality theory:

27 Ibid., p. 9.

${ }^{28}$ Stewart Goetz, The Purpose of Life: A Theistic Perspective (London: Continuum, 2012).

${ }^{29}$ The idea of things ultimately fitting together in an intelligible way is naturally captured in a narrative in which the end of the story is the fulfilment of the purpose of the author/creator and brings closure to a problem or problems. See Joshua W. Seachris, 'Death, Futility, and the Proleptic Power of Narrative Ending', in Joshua W. Seachris (ed.), Exploring the Meaning of Life: An Anthology and Guide (Malden, MA: Wiley-Blackwell, 2013), pp. 461-80.

${ }^{30}$ Metz, Meaning in Life, p. 27. For my thoughts about this issue, see my review of Meaning in Life in the Notre Dame Philosophical Review.

${ }^{31}$ Ibid., p. 240. 
$\left(\mathrm{FT}_{3}\right)$ A human person's life is more meaningful, the more that she, without violating certain moral constraints against degrading sacrifice, employs her reason and in ways that either positively orient rationality toward fundamental conditions of human existence, or negatively orient it towards what threatens them, such that the worse parts of her life cause better parts towards its end by a process that makes for a compelling and ideally original life-story; in addition, the meaning in a human person's life is reduced, the more it is negatively oriented towards fundamental conditions of human existence or exhibits narrative disvalue. ${ }^{32}$

If I understand Metz's view correctly, what meaning in life essentially comes down to is orienting one's reason toward understanding the explanations of things in the realms of the true, the good, and the beautiful. After making clear that a 'necessary condition of $\mathrm{X}$ is something that is required in order for $\mathrm{X}$ to obtain, whereas a fundamental condition of $\mathrm{X}$ is something that is responsible for the obtaining of $\mathrm{X},{ }^{33}$ he stresses that 'great meaning does not come from discovering mere coincidences' but 'from making discoveries of the sort that Darwin and Einstein did', where the former discovered that 'human life is in large part a function of natural selection' and the latter that 'the basic facts about the spatiotemporal universe [...] account for a large array of events in it. ${ }^{34}$ With Metz's repeated mention of people like Darwin, Einstein, Mother Teresa, Picasso, and Dostoyevsky, and his stress on the importance of employing one's reason about the true, the good, and the beautiful, I come away from reading Meaning in Life thinking that substantial meaning in life is out of the reach of most individuals. After all, even those who are not an Einstein or a Darwin rarely create great works of art (Picasso and Dostoyevsky) or achieve sainthood (Mother Teresa). At one point, Metz writes about 'certain uses of our intelligence [that] are the key to meaning [...] [where] the exemplars of meaning, viz., the true, the good, and the beautiful [...] [involve] the sophisticated use of reason., ${ }^{35}$ And elsewhere he claims that his 'fundamentality theory [...] takes fairly literally the idea that considerations of meaning in life are a matter of deep or profound concerns, which contrast with superficial interests. ${ }^{36}$ Nevertheless, he

\footnotetext{
32 Ibid., p. 235.

${ }^{33}$ Ibid., p. 226.

${ }^{34}$ Ibid., p. 229.

${ }^{35}$ Ibid., p. 43. My emphasis.

${ }^{36}$ Ibid., p. 219. My emphases.
} 
insists that 'the fundamentality theory is not vulnerable to the initially tempting objection that it is an overly intellectual theory'. ${ }^{37}$

I have found it hard not to succumb to the temptation, but rather than continuing to indulge it I will bring my essay to a close by emphasizing that while I believe questions about life's meaning are multiple in nature (see the beginning of this section), the most basic question concerns what, if anything, makes life worth living. And what makes it worth living is the experience of pleasure, which is available to all persons whether or not they are seeking the explanations of things (making a sophisticated use of their reason about deep or profound concerns). However, acknowledging the centrality of pleasure when thinking about the meaning of life does not entail intellectual pursuits concerning the true, the good, and the beautiful are meaningless. Metz uses 'significant' as a synonym for 'meaningful', and a hedonist like me about what basically makes life meaningful can agree with Metz that orienting one's reason toward the true and beautiful can be meaningful in the sense of being significant or important. Of course, its importance will not be fundamental but derivative in nature because of its link at some point to the experience of pleasure (or diminishment of pain) for the agent and/or others. And given that a rational orientation to the moral good is essentially a concern for the well-being of others, where that well-being consists of experiences of pleasure (and the absence of experiences of pain), then the meaning (significance, importance) of this orientation is also derivative in nature. Obviously, we all know that there are both moral and immoral ways to experience pleasure and that in this life the wicked all too often prosper, which leads to thought about the meaning of life in terms of whether or not things ultimately make sense. Metz writes that ' $\mathrm{t}$ ] hose of us who are resolute deontologists about morality still wish that the consequences had turned out well, after all. ${ }^{38} \mathrm{I}$ believe things can ultimately make sense only if God created us for the purpose that we experience perfect happiness and there is an afterlife in which this purpose can be fulfilled. Like Metz, 'I [...] crave immortality ${ }^{39}$ because I crave to be perfectly happy, which is something that I will never be in this world. ${ }^{40}$

\footnotetext{
${ }^{37}$ Ibid., p. 223.

${ }^{38}$ Ibid., p. 247.

${ }^{39}$ Ibid.

40 Thanks to Timothy Mawson and Joshua Seachris for reading and commenting on an earlier version of this paper.
} 